\title{
Does Control of Corruption Matter for Entrepreneurship in Emerging Economies: Evidence from Post-Communist Countries
}

\author{
Hasan Ghura1, Xiaqing Lị ${ }^{1}$, and Allam Hamdan² \\ ${ }^{1}$ College of Business, Arts and Social Sciences, Brunel University London, UK \\ ${ }^{2}$ College of Business \& Finance, Ahlia University, Bahrain
}

\section{Abstract}

Corruption has been shown to discourage entrepreneurship in both developed and developing countries. However, it is less clear to what extent corruption affects the development of institutions' impact on entrepreneurial activity in the context of emerging economies, such as those in the post-communist countries. This study used Institutional Economics as a conceptual framework with the aim of analysing the moderating effect of control of corruption (informal institution) on the relationship between formal institutions (such as the number of procedures, education and

Corresponding Author: Hasan Ghura

hasan.ghura@brunel.ac.uk

Received: 22 July 2019

Accepted: 16 September 2019

Published: 19 September 2019

Publishing services provided by Knowledge E

(c) Hasan Ghura et al. This article is distributed under the terms of the Creative Commons

Attribution License, which permits unrestricted use and redistribution provided that the original author and source are credited

Selection and Peer-review under the responsibility of the PwR Symposium Conference Committee.

\section{G OPEN ACCESS}

training, access to finance, and technology absorption) and entrepreneurial activity. The study used panel data of 14 post-communist countries and different secondary databases from the years 2006-2014. The article has several implications from both theoretical perspectives (advancing the application of Institutional Economics for the study of entrepreneurship) and from the practical point of view (providing insights for governmental policies interested in fostering higher entrepreneurial levels).

Keywords: Institutional Economics, Corruption, Entrepreneurship, Emerging Economies

\section{Introduction}

Entrepreneurship has been recognised as a driving force for sustainable economic growth in recent years (Acs and Szerb, 2010; Acs et al., 2014b). However, the above relationship is contingent upon the level of institutional development in a given country (Acs et al., 2014a). As argued by Baumol (1990), where institutions are effective, entrepreneurs are more likely to focus their energies towards productive activities and undertake new ventures. While scholars have analysed the relationship between formal institutions (laws and regulations) and entrepreneurship, the relationship between informal institutions (social norms and culture) and entrepreneurship remains understudied (Carlos et al., 2013; Castaño-Martínez et al., 2015; Fuentelsaz et al., 2015; Bjørnskov and Foss, 2016; Ghura et al, 2017). Moreover, despite the constant interactions between formal 
and informal institutions, the literature lacks consensus regarding such interactions and their impact on entrepreneurship (Williamson, 2000; Ghura et al., 2017).

Little is known about entrepreneurship dynamic in emerging economies: "economies that are increasingly moving to market orientation and seeking to rapidly advance economically" (Bruton et al., 2008, p. 1). While emerging economies are different from developed economies in that they lack well-developed institutions, often resulting in lower entrepreneurial activity (Ahlstrom et al., 2008; Bruton et al., 2008; Bruton et al., 2009), some post-communist emerging economies such as Estonia, Slovenia, and Slovakia have managed to close this gap and appear in the top 30 of the Global Entrepreneurship Index (Acs et al., 2014b). Shedding light on the varying degree in which post-communist countries have achieved entrepreneurship development. It is, therefore, imperative to understand the role of institutions (formal and informal) that have resulted in better performing entrepreneurial environment in the above countries. This is of particular importance as while reforming formal institutions (e.g., government regulations and education) is integral to the overall institutional effectiveness, such improvements do not necessarily guarantee increased entrepreneurial activity (Bruton et al., 2013). This phenomenon is evident in the case of former communist emerging economies; where on the surface, they have laws and regulations similar to those seen in developed economies, however, as commercial laws that affect entrepreneurship are not efficiently implemented, these institutions are not conducive to entrepreneurial activity (Feige, 1997; Smallbone and Welter, 2001; Aidis et al., 2008; Tonoyan et al., 2011; Smallbone et al., 2014).

Moreover, quintessential to the post-communist countries are high levels of corruption as the lingering legacy of the previous centrally planned economic systems (Smallbone and Welter, 2001; Tonoyan et al., 2010). Therefore, these countries can offer a useful context for a comprehensive theoretical understanding of the role of institutions (formal and informal) on entrepreneurship, and whether the improved institutional environment has helped the countries mentioned above increase their level of entrepreneurial activity (Bruton et al., 2008; Bruton et al., 2009). Moreover, due to the prevalence of corruption in these countries' institutions, there is a need to test corruption as a moderator in order to have a better understanding of institutional dynamics as most previous studies have treated corruption merely as a control variable (Bruton et al., 2008; Bruton et al., 2013; Pathak et al., 2015).

As a result, this study aims to examine the impact of informal institutions such as control of corruption on the relationship between formal institutions and entrepreneurial activity in the context of post-communist countries. Also, still missing from the literature 
is a large longitudinal panel study of country-level rates of entrepreneurship. Such panel data analysis is worth pursuing to enhance the validity of the research while considering sufficient controls to account for institutional differences in the context of post-communist economies (Bruton et al., 2008; Levie and Autio, 2011).

This paper proceeds as follows. First, we theorise about the effects of formal institutions, corruption and their interactions on entrepreneurship. Second, we describe our sample data and methodology. Third, we discuss and present the statistical results, and finally, the conclusions and future research are presented.

\section{Framework and Theoretical Background}

The pioneering work of Douglass North $(1990,2005)$ and Baumol $(1990)$ remains crucial to our understanding of the central role institutions play in entrepreneurship development. In this perspective, entrepreneurs, who set up organisations, adapt their activities and strategies in response to the market opportunities and limitations provided by the formal and informal institutions (Gnyawali and Fogel, 1994; Manolova et al., 2008). Institutions can be defined in this context as the "rules of the game in a society, or more formally, the constraints that shape human interaction" (North, 1990, p. 3). While formal institutions exist to decrease transaction, costs caused by laws and regulations, informal institutions intend to reduce uncertainties involved in human interaction (North, 2005). Therefore, as argued by North (1990), informal institutions that are culturally derived may constrain the changes and the improvements of formal institutions and vice versa.

In line with the seminal work of North (1990, 2005), Gnyawali and Fogel (1994) suggested an institutional framework inclusive of five dimensions of the entrepreneurial environment: government policies and procedures, social and economic factors, entrepreneurial and business skills, and financial and non-financial assistance to businesses. Moreover, recent empirical studies found Gnyawali and Fogel's (1994) framework conducive in examining the impact of institutional dimensions on entrepreneurial activity (Álvarez and Urbano, 2011; Fuentelsaz et al., 2015; Aparicio et al., 2016). Thus, this study is closely guided by Gnyawali and Fogel's (1994) entrepreneurial (i.e., institutional) framework and following North's $(1990,2005)$ propositions on institutional dynamics. In this respect, government procedures, education and training, access to credit and technology absorption are considered as formal institutions, whereas control of corruption is considered as an informal institution in this study. Our choice in selecting these formal institutions is informed by considerable evidence that these institutions are essential influencers of entrepreneurial activity (Álvarez and Urbano, 2011; Stenholm 
et al., 2013; Aparicio et al., 2016). Moreover, in accordance to the model, economic conditions, related to the economic growth of a specific country is included as a control variable in our study (Álvarez and Urbano, 2011; Álvarez et al., 2014).

Since the direct effect of formal institutions that are considered in this study as well as country-level control of corruption, has been empirically established in the existing literature: number of procedures (Urbano and Alvarez, 2014; Castaño-Martínez et al., 2015; Chowdhury et al., 2015; Fuentelsaz et al., 2015; Aparicio et al., 2016), access to credit (Castaño-Martínez et al., 2015; Fuentelsaz et al., 2015; Aparicio et al., 2016), education and training (Castaño-Martínez et al., 2015; Chowdhury et al., 2015; Fuentelsaz et al., 2015; Aparicio et al., 2016), technology absorption (Stenholm et al., 2013; Acs et al., 2014b), and corruption (El Harbi and Anderson, 2010; Aidis et al., 2012; Estrin et al., 2013; Chowdhury et al., 2015), we refrained from engaging in a lengthy review of those effects. Therefore, our conceptual framework is designed to analyse the moderating effects of control of corruption on the relationship between formal institutions and entrepreneurial activity, as shown in Figure 1.

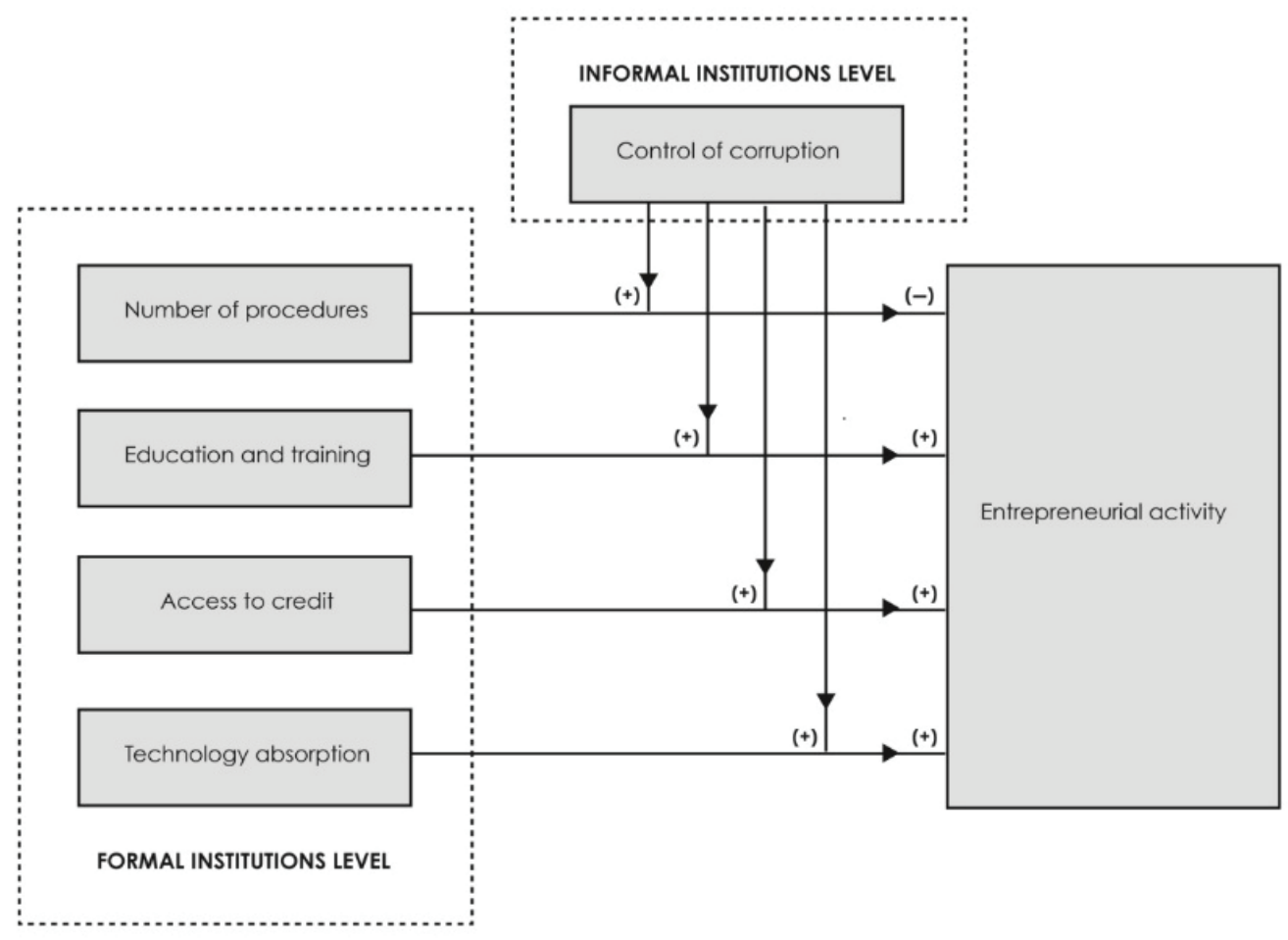

Figure 1: The developed conceptual framework of this study. 


\subsection{Control of Corruption and Entrepreneurship}

Although entrepreneurial activity is influenced by various informal institutions such as social networks (De Clercq et al., 2010; Estrin et al., 2013; Stenhom et al., 2013), cultural values (Hayton and Cacciotti, 2013; Fernández-Serrano and Liñán, 2014; FernándezSerrano and Romero, 2014; Sambharya and Musteen, 2014; Brancu et al., 2015), role models (Álvarez and Urbano, 2011), media attention (Stenholm et al., 2013), and social recognition (Stenholm et al., 2013; Urbano and Alvarez, 2014; Castaño-Martínez et al., 2015; Castaño et al., 2015, corruption has received very little attention. Corruption as an informal institution is purportedly among the most critical negative indicators that can potentially influence entrepreneurial activity through interaction with other formal institutions (Anokhin and Schulze, 2009). Scholars define corruption in the context of informal abuse of public assets for private gains that impacts resource allocation (Aidis et al., 2012; Payne et al., 2013; Chowdhury et al., 2015). In other words, corruption reflects the multidimensional impact of weak institutions in a given country (Tanzi, 1998; Payne et al., 2013). When corruption is widespread, it becomes embedded in the culture and is thus formed into a social norm of behaviour. Consequently, even if the change is introduced to formal institutional processes, corruption can potentially slow down the desired reforms outcomes (North, 1990; Williamson, 2000; Acemoglu and Robinson, 2006).

It is noteworthy, however, that the current literature is discrepant when it comes to ascribing the role of corruption on entrepreneurial activity and economic growth (Dreher and Gassebner, 2013; Dutta and Sobel, 2016). On the one hand, according to grease the wheel theory, corruption is suggested to help entrepreneurship by shortening the start-up process for aspiring entrepreneurs (Aidit, 2009, Dutta and Sobel, 2016). On the other hand, a larger body of research posited that corruption has a negative overall impact on economic development in the long run, due continuous rent-seeking from entrepreneurs by corrupt officials (Aidit, 2009; Anokhin and Schulze, 2009; Aidis et al., 2012; Avnimelech et al., 2014; Aparicio et al., 2016; Dutta and Sobel, 2016).

Therefore, in light of the current discrepancy, the hypotheses formed in this study aim to expand the understanding of the indirect effect of corruption as a moderator between formal institutions and entrepreneurial activity (Pathak et al. 2015). Following assertions of the signalling theory (Spence, 1973, 1974), formal institutions (e.g., business regulations) are likely to have a better impact on entrepreneurial activity in a corruptionfree environment (Levie and Autio, 2011). Thus, this study proposes that control of corruption may have a moderating effect on the relationship between formal institutions 
(i.e., the number of business procedures, education and training, access to credit and firm-level technology absorption) and entrepreneurial activity in the context of postcommunist countries (Payne et al., 2013).

\subsection{Control of Corruption and Number of Procedures for Entrepreneurship}

Gnyawali and Fogel (1994) suggested that governmental regulations such as the number of procedures, costs and taxes, among other factors, that are associated with starting a business have a negative connotation for potential entrepreneurs. For example, entrepreneurs in Australia spend two days to start-up a new venture while in Brazil it may take up to 152 days to establish a venture due to stringent regulations and extended length of time to acquire necessary permits and licenses (Klapper et al. 2006). Hence, these extensive business procedures may distract entrepreneurs from investing their resources in "productive" activities (Baumol 1990; Chowdhury et al., 2015).

Various studies have empirically posited the adverse effect of the number of procedures on entrepreneurial activity levels (Urbano and Alvarez, 2014; Castaño-Martínez et al., 2015; Chowdhury et al., 2015; Fuentelsaz et al., 2015; Aparacio et al., 2016). In line with the abovementioned empirical evidence, the Doing Business project at the World Bank advocates for regulation reduction, suggesting that simpler procedures further stimulate entrepreneurs to start new ventures. For example, "simplifying the formalities of registration was the most popular reform during the years 2007 and 2008, implemented in 49 countries" (Álvarez and Urbano, 2011, p. 35).

The above observations about the impact of procedures on entrepreneurship are particularly crucial in the context of emerging economies; since aspiring entrepreneurs in such economies must tackle issues such as volatile or ineffective regulations (Aidis et al., 2008). This argument is further applicable in the context of post-communist countries, which are characterised by higher levels of corruption (Smallbone and Welter, 2001; Tonoyan et al., 2010).

In this realm, Klapper and Love (2010) found that reforms in regards to reducing the number of procedures are more effective in countries with a better business environment. Conversely, he contended that reforms into procedures need much work in countries with fewer advantages business environment. In accordance to Klapper and Love's (2010) findings, control of corruption is one factor that could be beneficial to the society in terms of promoting greater trust in government reform policies and as such encourage aspiring entrepreneurs to formally register their ventures (Aparicio 
et al., 2016). This argument is further supported by Naudé (2008) who suggested that reducing corruption levels in the context of developing countries will ultimately lead to better and more efficient entry procedures and thus, allow for increased market entry of new ventures. To this end, this study hypothesizes that:

H1: Control of corruption moderates the negative relationship between the number of procedures and entrepreneurial activity such that the stronger the control of corruption, the stronger this relationship.

\subsection{Control of Corruption, Education and Training for Entrepreneurship}

Entrepreneurship education and training have been widely recognised to enhance entrepreneurial activity levels (Gnyawali and Fogel, 1994; Levie and Autio, 2008; Fuentelsaz et al., 2015). In particular, a tertiary educational system that focuses on developing skills and competencies in the areas of market analysis, product and service development, and business and financial literacy, enables entrepreneurs to establish and manage high growth ventures (Bowen and De Clercq, 2008; Danis and De Clercq, 2011; Jiménez et al., 2015). Therefore, an educational system with the focus on entrepreneurship is more likely to equip entrepreneurs with the necessary skills for business design and growth strategies and consequently, enable them to better exploit entrepreneurial opportunities in the market (Levie and Autio, 2008; Fuentelsaz et al., 2015).

Literature suggested that educated workforce is an essential ingredient for higher rates of entrepreneurship in the context of emerging economies (Baumol et al., 2007; Aidis et al., 2008; Valliere and Peterson, 2011). However, educated entrepreneurs may not react similarly to opportunities in all contexts, but rather their reactions may be conditioned by the institutional environment especially in the context of emerging economies (Baumol et al., 2007; Autio and Acs, 2010; Danis and De Clercq, 2011; Acs et al., 2014b). For example, Manolova et al. (2008) found that while some post-communist countries, such as Bulgaria, Hungary and Latvia have higher levels of education, these countries tend to exhibit lower rates of entrepreneurship due to entrepreneur's lack of confidence and required skills to start new businesses. Apart from the fact that this low confidence could be explained through political and social transition (Manolova et al., 2008), literature suggested that improving education would be more effective on increasing entrepreneurial activity levels if it is accompanied by more control of corruption (Álvarez and Urbano, 2011; Aparico et al., 2016). 
In this realm, Aparicio et al. (2016) contended that control of corruption increases trust in the system and as such, will create a better alliance between government policies and educational system. Moreover, Álvarez and Urbano (2011) suggested that control of corruption could allow future entrepreneurs to gain a greater share of their generated revenue and therefore, propel higher levels of entrepreneurial activity. Also, control of corruption would allow an increase in the amount of budget allocated to the education infrastructure and research and development (R\&D), which are extra variables to support entrepreneurial activity (Aparicio et al., 2016). Hence, controlling corruption could result in more opportunities for new venture creation (Aidis et al., 2008) based on technology and with higher added value (Aparicio et al., 2016). Therefore, in this study's context, the primary challenge for emerging economies is to overcome the high levels of corruption in order to improve the tertiary education and entrepreneurial activity levels (Acs et al., 2014a; Castaño et al., 2015; Aparicio et al., 2016). As a result, this study proposes the following hypothesis:

H2: Control of corruption moderates the positive relationship between education and training and entrepreneurial activity such that the stronger the control of corruption, the stronger this relationship.

\subsection{Control of Corruption, Access to Credit and Entrepreneurship}

As we mentioned earlier, financial support availability is among the most important pillars for entrepreneurs to start and grow their ventures (Gnyawali and Foger, 1994). Van Auken and Neely (1999) underscored the inadequacy in financial structure poses major obstacle to venture creation, as with no access to credit, individuals are unable to materialise their ideas, and as a result, the entrepreneurial activity decreases. Although new businesses may depend on personal funds received from informal investors such as family and social networks (Szerb et al., 2007), financial resources such as venture capital and bank loans are integral for aspiring entrepreneurs who seek to expand their businesses either locally or in foreign markets (Bowen and De Clercq, 2008; Korosteleva and Mickiewicz, 2011; Stenhom et al., 2013; Fuentelsaz et al., 2015; Aparicio et al., 2016). In this regard, Beck et al. (2005) found that entrepreneurs who face financial constraints such as high-interest rates, collateral requirements and lack of money in the banking system or face the need for special bank connections are less likely to exhibit venture growth rates. Conversely, Beck et al. (2008) found that small firms that obtain formal financing have better performance on several metrics in comparison with similar firms that depend on informal financing. To this end, various studies have suggested policies 
to improve access to bank credit through lowering capital requirements; credit with low-interest rates, and credit guarantee schemes, to promote new venture creation (Gnyawali and Fogel, 1994; Álvarez and Urbano, 2011; Bowen and DeClercq, 2008; Castaño-Martínez et al., 2015; Fuentelsaz et al., 2015; Aparicio et al., 2016).

The extent to which the financial system supports entrepreneurial activity in terms of providing resources to start and grow the business varies substantially across countries (Levie and Autio, 2008; Korosteleva and Mickiewicz, 2011; Chowdhury et al., 2015). In the context of emerging economies, the availability of financial resources is limited due to the lack of development in the financial institution (Aidis et al., 2008; Acs and Correa, 2014). In this regard, prior research suggested that higher levels of corruption and bribery adversely impact the development of a country's financial infrastructure (La Porta et al., 1999), and this uncertainty caused by corruption could generate distrust among entrepreneurs in the financial system, preventing its maturity (Aparicio et al., 2016). On the contrary, the prevalence of trust has been found to positively influence entrepreneurs to engage in high-growth business activities (Bowen and DeClercq, 2008). This suggests a potential interaction effect between a country's level of corruption and financial development on the one hand, and the new firm start-ups rates within its borders on the other (Bowen and DeClercq, 2008; Chowdhury et al., 2015).

Concerning the study's context, Johnson et al. (2002) analysed entrepreneurship in post-communist countries and found that extra-legal payments (bribes) hinder entrepreneurial activity more than the lack of financing. Therefore, corruption (as well as other deficiencies in the governance of a country) may increase transaction costs while limiting the income for entrepreneurs (Álvarez and Urbano, 2011). In turn, control of corruption may motivate increased entrepreneurial activity by allowing entrepreneurs to retain a greater share of their generated revenue (Álvarez and Urbano, 2011). As a result, we extend this argument by hypothesising that the presence of corruption free environment can leverage the financial system toward entrepreneurship (Korosteleva and Mickiewicz, 2011; Nofsinger and Wang, 2011; Aparicio et al., 2016). Thus:

H3: Control of corruption moderates the positive relationship between access to bank credit and entrepreneurial activity such that the stronger the control of corruption, the stronger this relationship. 


\subsection{Control of Corruption, Technology Absorption and Entrepreneurship}

The last formal institution analysed in this study is technology absorption (Gnyawali and Foger, 1994). The diffusion of new technology, as well as the capacity for firms to absorb it, is an essential factor for innovation and high growth ventures (Stenholm et al., 2013; Acs et al., 2014b). In this realm, improvements in information and communication technology (ICT) via internet (e.g., cloud computing, social media, internet of things, mobile phone services and big data analytics) may motivate individuals to start new businesses due to potential for higher returns such as better exchange information, fewer expenses and less time consuming (Acs 2006; Acs et al., 2008a). Hence, public policies that allow faster access to information and internet may further lead to more entrepreneurial activity and more innovation in the context of post-communist countries (Acs and Szerb 2007; Audretsch and Belitski, 2016).

However, as suggested by the literature, it is essential to remove barriers that hinder the development of technological infrastructure policies in the context of emerging economies (Acemoglu and Robinson, 2006; Pathak et al., 2015; Audretsch and Belitski, 2016). In particular, barriers, as mentioned earlier, may allude to the efforts by the political elite to block technological and institutional development in order to protect their benefits under the statuesque system (Acemoglu and Robinson, 2006). Thus, corrupt nations are less likely to benefit from FDI investment by high tech companies that are reluctant to enter markets accompanied by higher potential costs of corruption (Anokhin and Schulze, 2009). As a result, control of corruption may facilitate the transformation of new knowledge into new products and technology that ultimately fosters innovation and higher rates of entrepreneurial activity (Audretsch et al., 2008; Pathak et al., 2015). Thus, this study proposes the following hypothesis:

H4: Control of corruption moderates the positive relationship between technology absorption and entrepreneurial activity such that the stronger the control of corruption, the stronger this relationship.

\section{Data and Methodology}

Our data sources represent a sample of post-communist countries which fit the characterisations of emerging economies as suggested by Hoskisson et al. (2000). In this context, emerging economies are described as low-income countries that go through encouraging private enterprise development and increased economic liberalisation 
(Hoskisson et al., 2000). While these countries shared common histories concerning their pervasive corruption problems and inherited underdeveloped institutional legacies, differences in the pace and extent of economic liberalisation and institutional development provided the basis for our key research question (De Clercq et al., 2010; Kiss et al., 2012):

\section{Do formal institutions affect entrepreneurial activity levels in the same way under} both conditions of endemic corruption and freedom from it?

In addressing our research question, we analysed the moderating effect of an informal institution on the relationship between formal institutions and entrepreneurial activity in the context of post-communist countries. The variables analysed in this study included informal (control of corruption) and formal institutions (the number of procedures for starting a business, education and training, access to credit, and technology absorption by firms). The final sample consisted of 14 post-communist countries using a panel of data for the period 2006-2014 in which data were available for all key variables (i.e., dependent and independent variables) of the study (Appendix 1).

The data for this study is procured from different sources (Table 1). The dependent variable related to the entrepreneurial activity (NER) was derived from the World Bank Entrepreneurship Snapshot dataset which tracks the new entry rate of registered firms with government authorities (Acs et al., 2008b). This index is commonly used in the literature to compare entrepreneurial activity across countries (Acs et al., 2008b; Belitski et al., 2016). Moreover, it is particularly useful in accounting for "productive" entrepreneurship as aspiring entrepreneurs tend to register their ventures in order to benefit from the potential advantages of participating in the formal economy (Baumol, 1990; Klapper et al., 2010; Levie and Autio, 2011; Ghura et al., 2017).

The data about the informal institution, control of corruption (CC) as the independent variable, was obtained from the Worldwide Governance Indicators (WGI) project. Control of corruption (CC) captures perceptions of the extent to which public power is exercised for private gain, including both petty and grand forms of corruption, as well as "capture" of the state by elites and private interests. The scores in this database lie between -2.5 and 2.5, with higher scores corresponding to better outcomes of the institutions (Álvarez and Urbano, 2011; Aparicio et al., 2016).

Moreover, the source of data for the independent variables of formal institutions such as the number of procedures for starting a business (PRO) was taken from the World Bank's Doing Business project which provides the number of procedures that are officially required for an entrepreneur to start up and formally operate an industrial or commercial business (Álvarez and Urbano, 2011; Aparicio et al., 2016). The second 
TABLE 1: Description of variables.

\begin{tabular}{|c|c|c|c|}
\hline \multicolumn{2}{|c|}{ Variable } & \multirow{2}{*}{$\begin{array}{l}\text { Description } \\
\text { "The number of newly registered firms } \\
\text { with limited liability per } 1,000 \text { working-age } \\
\text { people (ages 15-64) per calendar year." }\end{array}$} & \multirow{2}{*}{$\begin{array}{l}\text { Source* } \\
\text { Doing Business } \\
2006 \text { to } 2014\end{array}$} \\
\hline $\begin{array}{l}\text { Dependant } \\
\text { variable }\end{array}$ & $\begin{array}{l}\text { New Entry Rate } \\
\text { (NER) }\end{array}$ & & \\
\hline $\begin{array}{l}\text { Environmental } \\
\text { factors Informal } \\
\text { institutions }\end{array}$ & $\begin{array}{l}\text { Control of } \\
\text { corruption (CC) }\end{array}$ & $\begin{array}{l}\text { "Control of corruption (CC) - capturing } \\
\text { perceptions of the extent to which public } \\
\text { power is exercised for private gain, } \\
\text { including both petty and grand forms of } \\
\text { corruption, as well as "capture" of the } \\
\text { state by elites and private interests. The } \\
\text { values are between }-2.5 \text { and } 2.5 \text { with } \\
\text { higher scores corresponding to better } \\
\text { outcomes of institutions." }\end{array}$ & WGI 2006-2014 \\
\hline \multirow[t]{4}{*}{$\begin{array}{l}\text { Environmental } \\
\text { factors formal } \\
\text { institutions }\end{array}$} & $\begin{array}{l}\text { Procedures for } \\
\text { starting a } \\
\text { business (PRO) }\end{array}$ & $\begin{array}{l}\text { "Natural logarithm of the product between } \\
\text { the number of procedures that are } \\
\text { officially required for an entrepreneur to } \\
\text { start up and formally operate an industrial } \\
\text { or commercial business and the duration } \\
\text { of these procedures." }\end{array}$ & $\begin{array}{l}\text { Doing Business } \\
2006 \text { to } 2014\end{array}$ \\
\hline & $\begin{array}{l}\text { Tertiary education } \\
\text { (TEDU) }\end{array}$ & $\begin{array}{l}\text { "Percentage of individuals who have } \\
\text { business and entrepreneurial skills. It is } \\
\text { obtained as the product of percentage of } \\
\text { tertiary graduates in the population } \\
\text { multiplied by percentage of tertiary } \\
\text { graduates in social sciences, business } \\
\text { and law." }\end{array}$ & $\begin{array}{l}\text { UNESCO } 2006 \text { to } \\
2014\end{array}$ \\
\hline & $\begin{array}{l}\text { Access to credit } \\
\text { (AC) }\end{array}$ & $\begin{array}{l}\text { "Domestic credit indicator provided by the } \\
\text { banking sector which includes all credit to } \\
\text { various sectors." }\end{array}$ & $\begin{array}{l}\text { World Bank } 2006 \\
\text { to } 2014\end{array}$ \\
\hline & $\begin{array}{l}\text { Firm-level } \\
\text { technology } \\
\text { absorption (TA) }\end{array}$ & $\begin{array}{l}\text { "To what extent do businesses in your } \\
\text { country absorb new technology? }[1=\text { not } \\
\text { at all; } 7 \text { = aggressively absorb]" }\end{array}$ & $\begin{array}{l}\text { Global } \\
\text { Competitiveness } \\
\text { Report } 2006 \text { to } \\
2014\end{array}$ \\
\hline Control variable & $\begin{array}{l}\text { GDP growth } \\
\text { (GDPg) }\end{array}$ & $\begin{array}{l}\text { "Annual percentage growth rate of GDP at } \\
\text { market prices based on constant local } \\
\text { currency. Aggregates are based on } \\
\text { constant } 2010 \text { U.S. dollars. GDP is the } \\
\text { sum of gross value." }\end{array}$ & $\begin{array}{l}\text { World Bank } 2006 \\
\text { to } 2014\end{array}$ \\
\hline \multicolumn{4}{|c|}{ 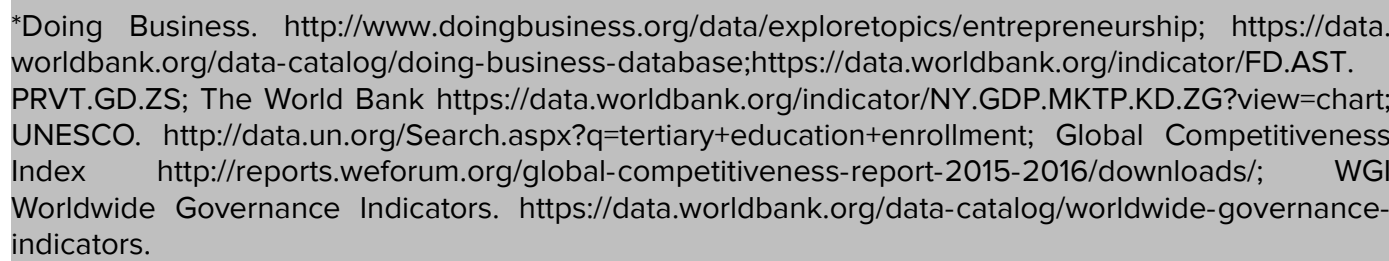 } \\
\hline
\end{tabular}

formal institution for the education and training variable (TEDU) was measured as the percentage of the population with tertiary education in the country, as obtained from the UNESCO database, indicating the percentage of the population with business and entrepreneurial skills (Álvarez and Urbano, 2011; Chowdhury et al., 2015). The third formal institution for access to credit (AC) was measured from the overall domestic credit to the private sector provided by banks as a share of GDP; it comes from the 
WDI dataset (Álvarez and Urbano, 2011). A final dimension of the formal institution is the availability of the latest technologies in a country (TA). This variable was measured from how favourable the environment is for the diffusion of technological change and was obtained from the Global Competitiveness Report (GCR) (Acs et al., 2008b; Stenholm et al., 2013).

Finally, given that the level of economic development of countries is considered a critical factor in explaining entrepreneurial activity (Wennekers et al., 2005; Acs et al., 2014a), this study controlled the country's annual percentage growth rate of GDP at market prices (GDPg). In line with other studies, these data sources were obtained from the World Bank (Bowen and De Clercq, 2008; Levie and Autio, 2011; Fuentelsaz et al., 2015).

Table 1 presents a list of dependent and independent variables used in this study, including their sources. Our final sample consisted of a balanced panel with data on 126 observations and 14 countries (see Appendix 1 for a list of post-communist countries with their mean values).

As the study's dataset deal with a relatively substantial number of cross-sectional units (14 post-communist countries) that have various characterisations (e.g., cultural values, religions, social norms, and using different currencies), it is more likely to have heterogeneity in panel data (Wooldridge, 2012). Therefore, this research applied the fixed effects (regression) model (FEM), which allows controlling for unobserved heterogeneity across countries that are fixed over time.

Based on the previous argument, this study proposed the following two models given below for the hypothesis's analyses; this indicated that a FEM provided a better fit for our data. However, this study takes into account that the FEM uses an only within-country variation, which impacts the interpretation of the results (Aidis et al., 2012).

$$
N E R_{i t}=\beta_{i}+\beta_{1} P R O_{i t}+\beta_{2} T E D U_{i t}+\beta_{3} A C_{i t}+\beta_{4} T A_{i t}+\beta_{5} C C_{i t}+\beta_{6} G D P g_{i t}+\varepsilon_{i t}
$$

$$
\begin{aligned}
N E R_{i t}= & \beta_{i}+\beta_{1} P R O_{i t}+\beta_{2} T E D U_{i t}+\beta_{3} A C_{i t}+\beta_{4} T A_{i t}+\beta_{5} C C_{i t}+\beta_{6}(P R O * C C)_{i t} \\
& +\beta_{7}(T E D U * C C)_{i t}+\beta_{8}(A C * C C)_{i t}+\beta_{9}(T A * C C)_{i t}+\beta_{10} G D P g_{i t}+\varepsilon_{i t}
\end{aligned}
$$

In model 1, $P R O_{i t}, T E D U_{i t}, A C_{i t}$ and $T A_{i t}$ are the vectors representing the formal institutions, while $C C_{i t}$ is the vector representing the informal institution. $G D P g_{i t}$ is the controlling vector that influences entrepreneurial activity in country $(i)$ at time $(t)$ which refers to the economic growth rate. 
In model 2, $(P R O * C C)_{i t},(T E D U * C C)_{i t},(A C * C C)_{i t}$ and $(T A * C C)_{i t}$ are the vectors representing the moderation effect of control of corruption between formal institutions and entrepreneurial activity.

\section{Results and Discussion}

Table 2 reports the means, standard deviations, and correlation coefficients of the variables used in this study. Our descriptive statistics showed that some variables might be highly correlated (e.g., control of corruption with education and training, credit and technology). Hence, to avoid the problem of multicollinearity, which could affect the significance of the main parameters in the regressions through Variance Inflation Factor (VIF) computations, we followed Aiken and West's (1991) procedures to assess the interaction effects. In this approach, we formed interaction terms by multiplying the mean-centred values of the interacting variables, then include these terms in one regression equation. This approach was adopted in different studies to minimise the possibility of multicollinearity (Danis et al., 2011). As a result, the VIF scores are below the cut-off value of 5, and thus, multicollinearity is not a concern in the analysis (Mehmetoglu and Jakobsen, 2017).

TABLE 2: Descriptive statistics and correlation matrix.

\begin{tabular}{l|l|l}
\hline & \\
& 1. New Entry Rate (NER) \\
\hline Informal & 2. Control of corruption (CC) \\
\hline Formal & 3. Procedures for starting a business (PRO) \\
& 4. Education and training (TEDU) \\
& 5. Access to credit (AC) \\
& 6. Firm-level technology absorption (TA) \\
\hline Control & 7. GDP growth (GDPg)
\end{tabular}

\begin{tabular}{|c|c|c|c|}
\hline \multicolumn{4}{|c|}{ Post-communist countries } \\
\hline Mean & Std. Dev. & Min & Max \\
\hline 4.67 & 3.21 & 0.81 & 16.25 \\
\hline 0.01 & 0.60 & -1.27 & 1.27 \\
\hline 6.17 & 2.01 & 3 & 11 \\
\hline 59.70 & 15.93 & 25.55 & 88.46 \\
\hline 49.00 & 20.58 & 6.17 & 101.26 \\
\hline 4.53 & 0.58 & 3.11 & 5.50 \\
\hline 2.64 & 5.36 & -14.81 & 13.75 \\
\hline
\end{tabular}

\begin{tabular}{l|c|c|c|c|c|c|c|c|} 
& $\mathbf{1}$ & $\mathbf{2}$ & $\mathbf{3}$ & $\mathbf{4}$ & $\mathbf{5}$ & $\mathbf{6}$ & $\mathbf{7}$ & $\mathbf{8}$ \\
\hline 1. NER & 1 & & & & & & \\
\hline 2. $\mathrm{CC}$ & $0.547^{* * *}$ & 1 & & & & & \\
\hline 3. PRO & $-0.251^{* *}$ & -0.108 & 1 & & & & \\
\hline 4. TEDU & $0.284^{* *}$ & $0.396^{* * *}$ & 0.083 & 1 & & & \\
\hline 5. AC & $0.576^{* * *}$ & $0.717^{* * *}$ & -0.144 & $0.627^{* * *}$ & 1 & & \\
\hline 6. TA & $0.416^{* * *}$ & $0.743^{* * *}$ & 0.064 & $0.529^{* * *}$ & $0.554^{* * *}$ & 1 & \\
\hline 7. GDPg & 0.021 & -0.142 & 0.141 & $-0.228^{*}$ & $-0.337^{* * *}$ & -0.102 & 1 \\
\hline *** $p<0.001 ;{ }^{* *} p<0.01 ;{ }^{*} p<0.10$ & & & & &
\end{tabular}


Aiming to analyse and compare the role of the institutional environment's effect on entrepreneurial activity, we created two different models. Model 1 included the direct effect of informal and formal factors for entrepreneurial activity, whereas Model 2 included the moderating effect of control of corruption on the relationship between formal institutions and entrepreneurial activity (see Table 3).

In order to estimate all the regressions, we tried to develop a panel data analysis. As discussed earlier, this study assumes that FEM was more appropriate to estimate Model 1 and 2 . This specification model enables us to study the impact of variables that vary over time (Wooldridge, 2012). Moreover, to address the possibility of heteroskedasticity, autocorrelation and cross-sectional dependence, we followed Roman's et al. (2018, p. 517) study and applied Driscoll and Kraay's (1998) "standard errors for the coefficients estimated by the within-group regression, robust to heteroskedasticity and the very general forms of cross-sectional and temporal dependence".

In Table 3, the results of Model 1 showed that corruption played a significant role in post-communist countries as it was significant at the $95 \%$ level and with the expected sign. Thus, living in a country where entrepreneurship has a high-level corruptionfree environment often increases the probability of entrepreneurial activity (Anokhin and Schulze, 2009; Aidis et al., 2012; Avnimelech et al., 2014; Aparicio et al., 2016; Dutta and Sobel, 2016). However, formal factors results were inconsistent in Model 1. In this regard, the relationship between the number of procedures for starting a business and entrepreneurial activity was significant at $(p<0.05)$ with a negative sign. In contrast, the relationship between education and training with entrepreneurial activity was not significant. Moreover, the relationship between access to credit and firm-level technology absorption with entrepreneurial activity was significant at the $95 \%$ level with a negative sign. These findings were contrary to previous studies which have suggested that education (Baumol et al., 2007; Aidis et al., 2008; Valliere and Peterson, 2011), access to capital (Bowen and De Clercq, 2008; Aparicio et al., 2016) and technology absorption (Gnyawali and Fogel, 1994; Stenholm et al., 2013; Acs et al., 2014b) are a critical success factor when developing new start-ups. This model explained $89 \%$ of the total variation of entrepreneurial activity.

The results of Model 2 (see Table 3) showed that the interaction effect of informal and formal institutions was related to the entrepreneurial activity. In this model, we included control of corruption as the moderating factor between the relationship of formal institutions and entrepreneurship. The results found that most of the moderating coefficients in this model were highly significant at $(p<0.01)$, the moderating coefficient 
TABLE 3: Regression analysis explaining entrepreneurial activity (NER).

\begin{tabular}{|c|c|c|}
\hline & $\begin{array}{l}\text { Model } 1 \text { Coef. } \\
\text { (std. error) }\end{array}$ & $\begin{array}{l}\text { Model } 2 \text { Coef. } \\
\text { (std. error) }\end{array}$ \\
\hline \multicolumn{3}{|l|}{ Informal institution } \\
\hline Control of corruption (CC) & $2.364^{*}(1.22)$ & $3.065^{* *}(1.08)$ \\
\hline \multicolumn{3}{|l|}{ Formal institutions } \\
\hline Procedures for starting a business (PRO) & $-0.227^{* *}(.040)$ & $-0.187^{* * *}(0.04)$ \\
\hline Business and entrepreneurial skills (TEDU) & $0.02(0.02)$ & $0.007(0.04)$ \\
\hline Access to credit (AC) & $-0.055^{* *}(0.02)$ & $-0.044^{* * *}(0.01)$ \\
\hline Firm-level technology absorption (TA) & $-1.482^{* *}(0.44)$ & $-1.441^{* * *}(0.29)$ \\
\hline $\begin{array}{l}\text { Control of corruption (CC) x Procedures for starting a } \\
\text { business (PRO) }\end{array}$ & & $-0.360^{* * *}(0.04)$ \\
\hline Control of corruption $(C C) \times$ Education and training (TEDU) & & $0.108^{* * *}(0.02)$ \\
\hline Control of corruption $(\mathrm{CC}) \times$ Access to credit $(\mathrm{AC})$ & & $-0.056^{* * *}(0.01)$ \\
\hline $\begin{array}{l}\text { Control of corruption (CC) x Firm-level technology absorption } \\
\text { (TA) }\end{array}$ & & $-1.363^{* *}(0.42)$ \\
\hline \multicolumn{3}{|l|}{ Control variable } \\
\hline GDP growth (GDPg) & $0.064^{* *}(0.02)$ & $0.044^{*}(0.02)$ \\
\hline Constant & $2.890^{* *}(1.08)$ & $3.978^{* *}(1.19)$ \\
\hline Prob.(F-statistic) & 0.000 & 0.000 \\
\hline $\mathrm{R}^{2}$ & 0.89 & 0.91 \\
\hline Observations & 126 & 126 \\
\hline Countries & 14 & 14 \\
\hline \multicolumn{3}{|l|}{ Notes: Driscoll-Kraay standard errors between parentheses. } \\
\hline${ }^{* * *} p<0.01 ;{ }^{* *} p<0.05 ;{ }^{*} p<0.1$ & & \\
\hline
\end{tabular}

of technology absorption was significant at $(p<0.05)$. Model 2 explains $91 \%$ of the total variation in entrepreneurial activity.

In comparison with Model 1, the results of Model 2 indicated that control of corruption has both a direct and indirect impact on entrepreneurial activity; thus, we confirmed the importance of the control of corruption to promoting entrepreneurial activity in post-communist countries as it behaved as a moderator as well (Pathak et al. 2015). Moreover, Model 2 showed a better framework than Model 1, as $\mathrm{R}^{2}$ explained $91 \%$ of the total variation of entrepreneurial activity.

Concerning the hypotheses testing, Hypothesis 1 suggested that the number of procedures for starting a business has a negative influence on entrepreneurship in each post-communist economy that has lower levels of corruption. While Model 1 showed that number of procedures has a negative and significant influence on entrepreneurial activity for each emerging economy $(\beta=-0.227 ; p<0.05$ ), Model 2 showed that the interaction effect between number of procedures and corruption has a negative and significant influence on entrepreneurial activity for each emerging economy ( $\beta=-0.360$; 
$p<0.01)$. The results showed that the interaction effect of control of corruption and the number of procedures coefficient is higher than the coefficient of the direct effect of the number of procedures in each post-communist economy, supporting Hypothesis 1. Although the results of Model 1 were congruent with the literature (the more days required for the creation of a new firm, the less likely it is that the entrepreneurial activity will occur) (Álvarez and Urbano, 2011; Aparicio et al., 2016), the results of Model 2 showed that the number of procedures has a better impact on entrepreneurial activity in post-communist economies that have lower levels of corruption as suggested by the literature (Naudé, 2008; Klapper and Love, 2010; Aparicio et al., 2016).

Hypothesis 2 proposed that lower levels of corruption positively influence the relationship between education and training with entrepreneurial activity in each postcommunist economy. While Model 1 showed that education and training were not significant to entrepreneurial activity, Model 2 showed that the interaction effect between education and training with corruption has a positive and highly significant influence on entrepreneurial activity $(\beta=0.108 ; p<0.01)$. The results for the moderating role of corruption were in line with our expectations, supporting Hypothesis 2. Therefore, an educational system with an entrepreneurial focus is more likely to increase entrepreneurial activity in emerging economies that have lower levels of corruption rather than higher levels of corruption as suggested by literature (Álvarez and Urbano, 2011; Aparicio et al., 2016).

Hypotheses 3 suggested that access to credit from banks has a positive influence on entrepreneurial activity in the context of each post-communist economy that has lower levels of corruption. While Model 1 showed that access to credit was significant with a negative sign to entrepreneurial activity, Model 2 also showed that the interaction effect between control of corruption and access to credit has a negative and significant influence on entrepreneurial activity $(\beta=-0.056 ; p<0.05)$. The interpretation of the previous results could be explained in three ways. First, the previous results could suggest that entrepreneurs who are associated with higher risk levels tend to obtain financial resources from social networks and family connections; this may be because existing financial institutions are underdeveloped and less likely to support their new ventures (Ho and Wong, 2007; Chowdhury et al., 2015b; Fuentelsaz et al., 2015; Ghura et al., 2017). Second, another interpretation for the findings was suggested by Wennekers et al. (2005), who argued that emerging economies have higher rates of necessity entrepreneurship (i.e., informal entrepreneurship), which does not require large amounts of credit. Lastly, although this latter idea could be right, the results also suggested that entrepreneurs may later depend on alternative sources to fund 
their growing businesses, such as venture capital funds, angel investors and corporate investors, due to the lack of adequate financial infrastructure (Bowen and De Clercq, 2008; Aidis, 2012; Ghura et al., 2017).

Finally, Hypotheses 4 suggested that firm-level technology absorption has a significant influence on entrepreneurship in each post-communist economy that has lower levels of corruption. The results were contrary to the study's expectations as the coefficient regression was significant with a negative sign in Model 1 and significant $(\beta=-1.363$; $p<0.05$ ) with a negative sign in Model 2 . Although not what we predicted, the previous results could suggest that new business activities in post-communist economies that have lower levels of corruption are still not technology-based and characterised by imitative entrepreneurship. In this regard, entrepreneurs in post-communist countries tend to copy technologies from developed economies to expand their economy of scale (Acs, 2006; Minniti and Lévesque, 2010). Entrepreneurs are, therefore, less likely to invest in $R \& D$, even though imitative entrepreneurship is significant to economic growth. This is especially true in the case of emerging economies, as they increase competition and product availability when the revenues to R\&D expenditure are low (Minniti and Levesque, 2010).

In general, the estimated coefficient of the control variable of economic growth was consistent with the existing literature (Models 1 and 2), which indicated a positive and significant influence between economic growth and entrepreneurial activity (Levie and Autio, 2011; Fuentelsaz et al., 2015).

To this end, the inconsistency of findings between model 1 and model 2 provided some support for the conceptual premise that it is essential to consider the interactions of formal and informal institutions and their impact on entrepreneurial activity (North 1990, 2005, Williamson, 2000; Acs et al., 2014a; Ghura et al., 2017). These results were in line with previous literature that suggested that certain institutional variables such as control of corruption can be conducive for entrepreneurial activity levels in the context of post-communist emerging economies (Aidis et al., 2008; Tonoyan et al., 2010; Bruton et al., 2013; Aparicio et al., 2016).

\section{Conclusion}

Considering that entrepreneurship is a key driver for economic growth and development (Acs et al., 2014a, b; Aparicio et al., 2016; Ghura et al., 2017), understanding which institutional variables contribute to fostering and enhancing entrepreneurship appears to be a remarkable phenomenon (Levie and Autio, 2011; Stenholm et al., 2013; Fuentelsaz 
et al., 2018; Urbano et al., 2018). In this thesis, balanced longitudinal panel data (for the period 2006-2014) were used to empirically examine the simultaneous effect of institutional variables on the development of entrepreneurial activity in the context of 14 post-communist economies. By developing a conceptual framework of institutional economics, this study analysed the interaction effect of informal (i.e., corruption) and formal institutions (i.e., the number of procedures involved in starting a business and education and training, access to credit, and technology absorption) on the rates of entrepreneurial activity.

The main findings shed more light on the importance of the environmental factors on entrepreneurship in which formal institutions such as the number of procedures necessary to create a new business, entrepreneurship education and training, access to finance, and technology absorption should have to be accompanied by more control of corruption (Álvarez and Urbano, 2011; Aparicio et al., 2016). Overall, control of corruption showed that it behaves as a moderator between formal institutions and entrepreneurship. In particular, the evidence from this study showed that formal institutions, such as the number of procedures, and education and training, are more likely to encourage individual's choice to become an entrepreneur and start a new business activity in postcommunist economies that have a perception of lower levels of corruption. Therefore, it is inappropriate for policymakers in post-communist countries to rely on the reform changes of the formal institutions without considering the reforms of the informal institutions, such as corruption.

The study has several contributions. First, it advanced the existing theory in the field of entrepreneurship and Institutional Economics as few empirical papers are grounded in both theories (Acs et al., 2014a, b). Second, we developed a theoretical model that explains factors that may influence the likelihood of individuals entering entrepreneurship. This study was among the first testing the moderating effect of control of corruption on formal institutions predicting entrepreneurial activity. Third, our findings have implications for policymakers who are interested in fostering and promoting entrepreneurship for the benefit of economic and productivity growth in the context of emerging economies.

The generalizability of the study's findings is subject to certain limitations that could become future research lines. First, more accurate measures for both dependent and independent variables could be used. On the one hand, our study has considered only one particular aspect of high-growth entrepreneurship, which is newly registered firms with limited liability. Although newly registered firms are recognised as one of the critical drivers that entrepreneurial activity may make to economic growth (Acs et al., 
2008b; Levie and Autio, 2011), future research should seek to examine other aspects of growth-oriented entrepreneurship such as activities involving a high level of innovation, corporate entrepreneurship or technology developments (Bowen and De Clercq, 2008; Turro et al., 2014). On the other hand, using other (or more) environmental variables (e.g., national culture) is crucial to understanding entrepreneurship in emerging countries where institutional arrangements can vary significantly from those in developed countries (Bruton et al., 2008; Hayton and Cacciotti, 2013; Fernández-Serrano and Liñán, 2014; Fernández-Serrano and Romero, 2014; Sambharya and Musteen, 2014; Brancu et al., 2015). Second, the examined models to explain entrepreneurial activity through institutions are quite adequate and robust, but it is necessary to complement them and consider emerging economies at different levels of economic development (Stenholm et al., 2013; Acs et al., 2014a). Third, it is recommended that further research is undertaken in larger samples across more countries or in different regions such as resource-based economies, African or Asian contexts in which corruption is prevalent in many of those nations (Pathak et al., 2015). We hope that our study will inspire further investigations in future into the interaction's impact between formal and informal institutions on entrepreneurial activity.

\section{Appendix 1: Mean values for Post-Communist Countries}

\begin{tabular}{lccccccc} 
Country 2006-2014 & NER(1) & CC(2) & PRO(3) & TEDU(4) & AC(5) & TA(6) & GDPg(7) \\
1. Armenia & 1.41 & -0.57 & 5.89 & 46.11 & 28.31 & 4.27 & 4.52 \\
2. Croatia & 3.36 & 0.03 & 8.11 & 55.81 & 66.28 & 4.43 & -0.12 \\
3. Czech Republic & 2.94 & 0.27 & 8.78 & 61.19 & 45.33 & 5.22 & 1.78 \\
\hline 4. Estonia & 13.12 & 0.98 & 5.00 & 69.29 & 81.56 & 5.43 & 1.81 \\
5. Georgia & 3.88 & 0.06 & 4.22 & 33.11 & 32.78 & 4.00 & 5.36 \\
6. Hungary & 5.14 & 0.35 & 5.78 & 61.22 & 53.50 & 4.86 & 0.62 \\
7. Kyrgyz Republic & 0.96 & -1.16 & 5.44 & 44.13 & 12.81 & 3.61 & 4.81 \\
8. Latvia & 8.80 & 0.21 & 4.56 & 71.99 & 75.70 & 4.62 & 1.69 \\
9. Lithuania & 3.31 & 0.22 & 6.44 & 80.24 & 52.21 & 5.05 & 2.76 \\
10. Macedonia & 4.82 & -0.11 & 5.67 & 38.26 & 41.95 & 3.76 & 3.17 \\
11. Romania & 4.86 & -0.19 & 6.22 & 59.84 & 35.10 & 4.31 & 2.65 \\
12. Russian Federation & 4.49 & -0.99 & 7.39 & 75.75 & 43.10 & 4.06 & 3.16 \\
13. Slovak Republic & 4.33 & 0.22 & 6.89 & 53.44 & 43.69 & 5.05 & 3.67 \\
14. Slovenia & 3.98 & 0.88 & 6.00 & 85.08 & 73.22 & 4.78 & 1.04
\end{tabular}

(1) “The number of newly registered firms with limited liability per 1,000 working-age people (ages 15-64) per calendar year." 
(2) "Capturing perceptions of the extent to which public power is exercised for private gain, including both petty and grand forms of corruption, as well as "capture" of the state by elites and private interests. The values are between -2.5 and 2.5 with higher scores corresponding to better outcomes of institutions."

(3) "Natural logarithm of the product between the number of procedures that are officially required for an entrepreneur to start up and formally operate an industrial or commercial business and the duration of these procedures."

(4) "Percentage of individuals who have business and entrepreneurial skills. It is obtained as the product of percentage of tertiary graduates in the population multiplied by percentage of tertiary graduates in social sciences, business and law."

(5) "Domestic credit indicator provided by the banking sector which includes all credit to various sectors." (6) "To what extent do businesses in your country absorb new technology? [ 1 = not at all; 7 = aggressively absorb]."

(7) "Annual percentage growth rate of GDP at market prices based on constant local currency. Aggregates are based on constant 2010 U.S. dollars. GDP is the sum of gross value."

\section{References}

[1] Acemoglu, D., and Robinson, J. A. (2006), "Economic backwardness in political perspective", American Political Science Review", Vol. 100 No 1, pp. 115-131.

[2] Acs, Z. (2006), "How is entrepreneurship good for economic growth?", Innovations, Vol. 1 No. 1, pp. 97-107.

[3] Acs, Z. J., and Correa, P. G. (2014), "Identifying the obstacles to high-Impact entrepreneurship in Latin America and the Caribbean", The World Bank, pp. 1-32.

[4] Acs, Z.J., Desai, S. and Hessels, J. (2008a), "Entrepreneurship, economic development and institutions", Small Business Economics, Vol. 31 No. 3, pp. 219234.

[5] Acs, Z. J., Desai, S., and Klapper, L. F. (2008b), "What does "entrepreneurship" data really show?", Small Business Economics, Vol. 31 No 3, pp. 265-281.

[6] Acs, Z. J., and Szerb, L. (2007), "Entrepreneurship, economic growth and public policy", Small business economics, Vol. 28 No. 2-3, pp. 109-122.

[7] Acs, Z.J. and Szerb, L. (2010), “Global Entrepreneurship and the United States”, Small Business Administration, Washington, DC.

[8] Acs, Z.J., Autio, E. and Szerb, L. (2014a), "National systems of entrepreneurship: measurement issues and policy implications”, Research Policy, Vol. 43 No. 3, pp. 476-494.

[9] Acs, Z.J., Szerb, L. and Autio, E. (2014b), "The global entrepreneurship and development index", in Lloyd, A. (Ed.), Global Entrepreneurship and Development Index 2014, The Global Entrepreneurship and Development Institute, Washington, DC, pp. 1-120. 
[10] Ahlstrom, D., Bruton, G. D., and Yeh, K. S. (2008), "Private firms in China: Building legitimacy in an emerging economy", Journal of world business, Vol. 43 No 4, pp. 385-399.

[11] Aidis, R., Estrin, S., and Mickiewicz, T. (2008), "Institutions and entrepreneurship development in Russia: A comparative perspective", Journal of Business Venturing, Vol. 23 No. 6, pp. 656-672.

[12] Aidis, R., Estrin, S. and Mickiewicz, T.M. (2012), "Size matters: entrepreneurial entry and government", Small Business Economics, Vol. 39 No. 1, pp. 119-139.

[13] Aidt, T. S. (2009), "Corruption, institutions, and economic development" Oxford Review of Economic Policy, Vol. 25 No. 2, pp. 271-291.

[14] Aiken, L.S. and West, S.G. (1991), "Multiple regression: Testing and interpreting interactions", Sage, Newbury Park, CA.

[15] Álvarez, C. and Urbano, D. (2011), "Environmental factors and entrepreneurial activity in Latin America", Academia. Revista Latinoamericana de Administración, No. 48, pp. 31-45, available at: https://papers.ssrn.com/sol3/papers.cfm?abstract_id=1974138

[16] Álvarez, C., Urbano, D. and Amorós, J.E. (2014), "GEM research: achievements and challenges", Small Business Economics, Vol. 42 No. 3, pp. 445-465.

[17] Anokhin, S. and Schulze, W.S. (2009), "Entrepreneurship, innovation, and corruption", Journal of Business Venturing, Vol. 24 No. 5, pp. 465-476.

[18] Aparicio, S., Urbano, D. and Audretsch, D. (2016), "Institutional factors, opportunity entrepreneurship and economic growth: panel data evidence", Technological Forecasting and Social Change, Vol. 102 No. C, pp. 45-61.

[19] Audretsch, D. B., Bönte, W., \& Keilbach, M. (2008), "Entrepreneurship capital and its impact on knowledge diffusion and economic performance", Journal of business venturing, Vol. 23 No. 6, pp. 687-698.

[20] Audretsch, D. B., and Belitski, M. (2016), "Entrepreneurial ecosystems in cities: establishing the framework conditions", The Journal of Technology Transfer, Vol. 42 No.5, pp. 1030-1051.

[21] Autio, E., and Acs, Z. (2010), "Intellectual property protection and the formation of entrepreneurial growth aspirations" Strategic Entrepreneurship Journal, Vol. 4 No. 3, pp. 234-251.

[22] Avnimelech, G., Zelekha, Y., and Sharabi, E. (2014), "The effect of corruption on entrepreneurship in developed vs non-developed countries", International Journal of Entrepreneurial Behaviour \& Research, Vol. 20 No. 3, pp. 237-262.

[23] Baumol, W.J. (1990), "Entrepreneurship: productive, unproductive, and destructive", Journal of Political Economy, Vol. 98 No. 5, pp. 893-921. 
[24] Baumol, W.J., Litan, R.E. and Schramm, C.J. (2007), Good Capitalism, Bad Capitalism, and the Economics of Growth and Prosperity, Yale University Press, New Haven.

[25] Beck, T., Demirgüç-Kunt, A.S.L.I. and Maksimovic, V. (2005), "Financial and legal constraints to growth: does firm size matter?", The Journal of Finance, Vol. 60 No. 1, pp. 137-177.

[26] Beck, T., Demirgüç-Kunt, A. and Maksimovic, V. (2008), “Financing patterns around the world: are small firms different?", Journal of Financial Economics, Vol. 89 No. 3, pp. 467-487.

[27] Belitski, M., Chowdhury, F. and Desai, S. (2016), “Taxes, corruption, and entry”, Small Business Economics, 47(1), 201-216.

[28] Bjørnskov, C., and Foss, N. J. (2016). "Institutions, Entrepreneurship, and Economic Growth: What Do We Know and What Do We Still Need to Know?", The Academy of Management Perspectives, Vol. 30 No. 3, pp. 292-315.

[29] Bowen, H.P. and De Clercq, D. (2008), "Institutional context and the allocation of entrepreneurial effort", Journal of International Business Studies, Vol. 39 No. 4, pp. 747-767.

[30] Brancu, L., Guðmundsdóttir, S., Gligor, D., and Munteanu, V. (2015), "Is Culture a Moderator of Entrepreneurship Motivation? A Comparative Study of Romania and Iceland" Amfiteatru Economic, Vol. 17 No. 38, pp. 133-147.

[31] Bruton, G.D., Ahlstrom, D. and Obloj, K. (2008), "Entrepreneurship in emerging economies: where are we today and where should the research go in the future", Entrepreneurship Theory and Practice, Vol. 32 No. 1, pp. 1-14.

[32] Bruton, G. D., Ahlstrom, D., and Puky, T. (2009), "Institutional differences and the development of entrepreneurial ventures: A comparison of the venture capital industries in Latin America and Asia”, Journal of International Business Studies, Vol. 40 No. 5 , pp. $762-778$.

[33] Bruton, G. D., Filatotchev, I., Si, S., and Wright, M. (2013), "Entrepreneurship and strategy in emerging economies", Strategic Entrepreneurship Journal, Vol. 7 No. 3, pp. 169-180.

[34] Carlos Díaz Casero, J., Almodóvar González, M., de la Cruz Sánchez Escobedo, M., Coduras Martinez, A. and Hernández Mogollón, R. (2013), "Institutional variables, entrepreneurial activity and economic development", Management Decision, Vol. 51 No. 2, pp. 281-305.

[35] Castaño, M.S., Méndez, M.T. and Galindo, M.Á. (2015), “The effect of social, cultural, and economic factors on entrepreneurship", Journal of Business Research, Vol. 68 No. 7, pp. 1496-1500. 
[36] Castaño-Martínez, M.S., Méndez-Picazo, M.T. and Galindo-Martín, M.Á. (2015), "Policies to promote entrepreneurial activity and economic performance", Management Decision, Vol. 53 No. 9, pp. 2073-2087.

[37] Chowdhury, F., Terjesen, S. and Audretsch, D. (2015), "Varieties of entrepreneurship: institutional drivers across entrepreneurial activity and country", European Journal of Law and Economics, Vol. 40 No. 1, pp. 121-148.

[38] Danis, W. M., De Clercq, D., and Petricevic, O. (2011), "Are social networks more important for new business activity in emerging than developed economies? An empirical extension", International Business Review, Vol. 20 No. 4, pp. 394-408.

[39] De Clercq, D., Danis, W.M. and Dakhli, M. (2010), "The moderating effect of institutional context on the relationship between associational activity and new business activity in emerging economies", International Business Review, Vol. 19 No. 1, pp. 85-101.

[40] Dreher, A., and Gassebner, M. (2013), "Greasing the wheels? The impact of regulations and corruption on firm entry", Public Choice, Vol. 155 No. 3, pp. 413432.

[41] Driscoll, J.C. and Kraay, A.C. (1998), Consistent covariance matrix estimation with spatially dependent panel data, Review of economics and statistics, 80(4), 549-560.

[42] Dutta, N., and Sobel, R. (2016), “Does corruption ever help entrepreneurship?” Small Business Economics, Vol. 47 No. 1, pp. 179-199.

[43] El Harbi, S. and Anderson, A.R. (2010), "Institutions and the shaping of different forms of entrepreneurship", The Journal of Socio-Economics, Vol. 39 No. 3, pp. 436-444.

[44] Estrin, S., Korosteleva, J. and Mickiewicz, T. (2013), "Which institutions encourage entrepreneurial growth aspirations?", Journal of Business Venturing, Vol. 28 No. 4, pp. 564-580.

[45] Feige, E. L. (1997). "Underground activity and institutional change: Productive, protective and predatory behaviour in transition economies", Transforming postcommunist political economies, pp. 21-34. National Academy Press, Washington, D.C.

[46] Fernández-Serrano, J., and Liñán, F. (2014), “Culture and entrepreneurship: The case of Latin America", Innovar, Vol. 24(SPE), 169-180.

[47] Fernández-Serrano, J. and Romero, I. (2014), "About the interactive influence of culture and regulatory barriers on entrepreneurial activity", International Entrepreneurship and Management Journal, Vol. 10 No. 4, pp. 781-802. 
[48] Fuentelsaz, L., González, C., Maícas, J.P. and Montero, J. (2015), "How different formal institutions affect opportunity and necessity entrepreneurship", BRQ Business Research Quarterly, Vol. 18 No. 4, pp. 246-258.

[49] Ghura, H., Li, X., and Harraf, A. (2017), "Moderating relationship of institutions for opportunity entrepreneurship and economic development: Literature review and proposed conceptual framework", World Journal of Entrepreneurship, Management and Sustainable Development, Vol. 13 No 4, pp. 350-374.

[50] Gnyawali, D.R. and Fogel, D.S. (1994), "Environments for entrepreneurship development: key dimensions and research implications", Entrepreneurship Theory and Practice, Vol. 18 No. 4, p. 43.

[51] Hayton, J.C. and Cacciotti, G. (2013), "Is there an entrepreneurial culture? A review of empirical research", Entrepreneurship \& Regional Development, Vol. 25 Nos 9-10, pp. 708-731.

[52] Hoskisson, R. E., Eden, L., Lau, C. M., and Wright, M. (2000), "Strategy in emerging economies", Academy of management journal, Vol. 43 No. 3, pp. 249-267.

[53] Jiménez, A., Palmero-Cámara, C., González-Santos, M.J., Gonzalez-Bernal, J. and Jiménez Eguizábal, J.A. (2015), "The impact of educational levels on formal and informal entrepreneurship", BRQ Business Research Quarterly, Vol. 18 No. 3, pp. 204-212.

[54] Johnson, S., McMillan, J., \& Woodruff, C. (2002), "Property rights and finance", American Economic Review, Vol. 92 No.5, pp. 1335-1356.

[55] Klapper, L., Laeven, L., and Rajan, R. (2006), “Entry regulation as a barrier to entrepreneurship", Journal of financial economics, Vol. 82 No. 3, pp. 591-629.

[56] Klapper, L., Amit, R. and Guillén, M.F. (2010), "Entrepreneurship and firm formation across countries", in Lerner, J. and Schoar, A. (Eds), International Differences in Entrepreneurship, University of Chicago Press, Chicago, IL, pp. 129-158, available at: http://press.uchicago.edu/ucp/books/book/chicago///bo8648214.html

[57] Klapper, L., and Love, I. (2010), “The impact of business environment reforms on new firm registration", The World Bank, No. 5493, pp. 1-50.

[58] Kiss, A. N., Danis, W. M., and Cavusgil, S. T. (2012), "International entrepreneurship research in emerging economies: A critical review and research agenda". Journal of Business Venturing, Vol. 27 No. 2, pp. 266-290.

[59] Korosteleva, J., and Mickiewicz, T. (2011), "Start-up financing in the age of globalization", Emerging Markets Finance and Trade, Vol. 47 No. 3, pp. 23-49.

[60] La Porta, R., Lopez-de-Silanes, F., and Shleifer, A. (1999), "Corporate ownership around the world", Journal of Finance, Vol. 54 No.2, pp. 471-517 
[61] Levie, J. and Autio, E. (2008), "A theoretical grounding and test of the GEM model", Small Business Economics, Vol. 31 No. 3, pp. 235-263.

[62] Levie, J. and Autio, E. (2011), "Regulatory burden, rule of law, and entry of strategic entrepreneurs: an international panel study", Journal of Management Studies, Vol. 48 No. 6 , pp. 1392-1419.

[63] Manolova, T.S., Eunni, R.V. and Gyoshev, B.S. (2008), "Institutional environments for entrepreneurship: evidence from emerging economies in Eastern Europe", Entrepreneurship Theory and Practice, Vol. 32 No. 1, pp. 203-218.

[64] Minniti, M. and Lévesque, M. (2010), "Entrepreneurial types and economic growth", Journal of Business Venturing, 25(3), 305-314.

[65] Mehmetoglu, M. and Jakobsen, T.G. (2017), "Applied statistics using Stata: a guide for the social sciences", Sage, London.

[66] Naudé, W. (2008), "Entrepreneurship in economic development", World Institute for Development Economics Research, Research Paper 2008/20.

[67] Nofsinger, J. R., and Wang, W. (2011), “Determinants of start-up firm external financing worldwide" Journal of Banking and Finance, Vol. 35 No.9, pp. 2282-2294.

[68] North, D.C. (1990), Institutions, Institutional Change and Economic Performance, Cambridge University Press, New York, NY.

[69] North, D.C. (2005), Understanding the Process of Institutional Change, Princeton University Press, Princeton, NJ.

[70] Pathak, S., Xavier-Oliveira, E., and Laplume, A. O. (2015), "Entrepreneurship in transition economies: The role of corruption and individual attributes", Journal of Balkan and Near Eastern Studies, Vol. 17 No. 4, pp. 427-446.

[71] Payne, G.T., Moore, C.B., Bell, R.G. and Zachary, M.A. (2013), "Signaling organizational virtue: an examination of virtue rhetoric, country-level corruption, and performance of foreign IPOs from emerging and developed economies", Strategic Entrepreneurship Journal, Vol. 7 No. 3, pp. 230-251.

[72] Roman, A., Bilan, I. and Ciumaș, C. (2018), "What drives the creation of new businesses? A panel-data analysis for EU countries", Emerging Markets Finance and Trade, 54(3), 508-536.

[73] Sambharya, R. and Musteen, M. (2014), "Institutional environment and entrepreneurship: an empirical study across countries", Journal of International Entrepreneurship, Vol. 12 No. 4, pp. 314-330.

[74] Stenholm, P., Acs, Z.J. and Wuebker, R. (2013), "Exploring country-level institutional arrangements on the rate and type of entrepreneurial activity", Journal of Business Venturing, Vol. 28 No. 1, pp. 176-193. 
[75] Smallbone, D., and Welter, F. (2001), "The distinctiveness of entrepreneurship in transition economies", Small business economics, Vol. 16 No. 4, pp. 249-262.

[76] Smallbone, D., Welter, F., and Ateljevic, J. (2014), "Entrepreneurship in emerging market economies: Contemporary issues and perspectives", International Small Business Journal, Vol. 32 No. 2, pp. 113-116.

[77] Spence, M. (1973), “Job market signaling”, Quarterly Journal of Economics, Vol. 87, pp. 355-74.

[78] Spence, M. A. (1974), "Market Signaling: Informational Transfer in Hiring and Related Screening Processes", Cambridge, MA: Harvard Business Press.

[79] Szerb, L., Rappai, G., Makra, Z., and Terjesen, S. (2007), "Informal investment in transition economies: Individual characteristics and clusters", Small Business Economics, Vol. 28 No. 2, pp. 257-271.

[80] Tanzi, V. (1998), "Corruption around the world: causes, consequences, scope, and cures", Staff Papers, Vol. 45 No. 4, pp. 559-594.

[81] Tonoyan, V., Strohmeyer, R., Habib, M., and Perlitz, M. (2010), "Corruption and entrepreneurship: How formal and informal institutions shape small firm behaviour in transition and mature market economies", Entrepreneurship Theory and Practice, Vol. 34 No. 5, pp. 803-831.

[82] Turró, A., Urbano, D., \& Peris-Ortiz, M. (2014), “Culture and innovation: The moderating effect of cultural values on corporate entrepreneurship", Technological Forecasting and Social Change, Vol. 88, pp. 360-369.

[83] Urbano, D. and Alvarez, C. (2014), "Institutional dimensions and entrepreneurial activity: an international study", Small Business Economics, Vol. 42 No. 4, pp. 703-716.

[84] Urbano, D., Aparicio, S. and Audretsch, D. (2018), "Twenty-five years of research on institutions, entrepreneurship, and economic growth: what has been learned?", Small Business Economics, 1-29, https://doi.org/10.1007/s11187-018-0038-0.

[85] Valliere, D. and Peterson, R. (2009), "Entrepreneurship and economic growth: evidence from emerging and developed countries", Entrepreneurship \& Regional Development, Vol. 21 Nos 5-6, pp. 459-480.

[86] Van Auken, H.E., Neely, L. (1999), "Obstacles to business launch", Journal of development Entrepreneurship, Vol. 4 No. 2, pp. 175-187.

[87] Wennekers, S., Van Wennekers, A., Thurik, R. and Reynolds, P. (2005), "Nascent entrepreneurship and the level of economic development", Small Business Economics, Vol. 24 No. 3, pp. 293-309.

[88] Williamson, O.E. (2000), "The new institutional economics: taking stock, looking ahead", Journal of Economic Literature, Vol. 38 No. 3, pp. 595-613. 
[89] Wooldridge, J.M. (2012), "Introductory econometrics: A modern approach". South Western, Cengage learning, USA. 